\title{
CrimRxiv
}

\section{Seeing is Believing: How the Layering of Race is Obscured by "White Epistemologies" in the Criminal Justice Field}

Alpa Parmar, Rod Earle, Coretta Phillips

Published on: Feb 05, 2022

DOI: 10.21428/cb6ab371.c0298c32

License: Creative Commons Attribution 4.0 International License (CC-BY 4.0). 
